\title{
Usa Facing to Challenge for the Future: Domination or Cooperation? the Final Choice
}

\author{
Fabrizio Pezzani* \\ Department of Pharmacology, Bocconi University, Italy \\ *Corresponding author: Fabrizio Pezzani, Department of Pharmacology, Bocconi University, Italy
}

\begin{abstract}
The path we have attempted to describe briefly in the previous pages shows the evolution of a society that no longer seems able to make head or tail of what is going on in a moment of great difficulty. An incredulous society faced with facts it fails to understand but that it seems incapable of questioning. It remains locked in an ideological impasse between the return to ancient glories and ostentation of the past, and the idea that instead a new road must be found at the end of a journey that has come to a dead-end. So it is driven towards a form of "compulsion to repeat in a regressive manner". In 1949 British historian A. J. Toynbee in his book entitled Civilization on Trial made the point that an individual's character (and I would say also human society's) is always forged by having to face setbacks and obstacles. However, the toughest situations are those that arise in the middle of fortunate, prosperous periods that people fatuously believe can never end. In such situations people, fighting with destiny, give in to the temptation of looking for scapegoats who will bear the burden of their own incompetence. But trying to saddle someone else with one's own responsibilities in hard times is even more dangerous than believing in everlasting prosperity. Toynbee postulated that the real challenge at that time came from Western society's enormous technical progress that made it the master of non-human nature. It was indeed this magnificent advance in the knowledge of "secrets" that had illuded the past generation to the point of daydreaming that conveniently history had come full circle [1-4].

The extremely perspicacious Toynbee already saw the risk of a decline of our society. Much water has passed under the bridge of history, but his considerations have indeed been borne out, also as regards the role of Asia in terms of global domination. In fact in his posthumous work Mankind and Mother Earth Toynbee already saw that Western Europe had lost its leading role to the United States. Having said this he believed that American supremacy would not last longer than that of the Mongol Empire a mere two generations! Looking ahead, he felt that it was quite likely that leadership in the future would pass from America to East Asia [5,6]. Today we are facing a new chapter in history, one in which the United States must try to map out the role it intends to play. Whether this will be oriented towards a dangerous hegemony or possibly will experiment a role that is more oriented towards promoting cooperation. As the great Bard wrote -'To be or not to be: that is the question'. For the very first time after the collapse of the Soviet empire, the United States is faced with a new situation. It no longer has a well-defined enemy as the USSR had been; it is no longer the world's only power as has been the case for the past twenty years; it can no longer play a dominant role, because its very own history means that its cultural model is now open to debate. It seems unsure of which role to play: one of continuity with the past twenty years or one more oriented towards the legitimation of a position focused on reducing global tensions [6-12].
\end{abstract}

\section{Introduction}

This doubt sums up the country's dilemma. On the one hand Obama is in favour of a constructive dialogue, one not only based on military power. On the other hand his political opponents consider this to be a sign of weakness, they want the US to continue to play the dominant yet disastrous role embarked on in the Bush era. But times have changed and this position is no longer tenable. The Republicans' deep-rooted cultural model has led them to believe they are omnipotent, making Obama's rivals incapable of learning history's lesson and turning over a new leaf [13]. To think that America's first Republican president, Abraham Lincoln, in the middle of an extremely stormy period reminded Americans that: 'The dogmas of the quiet past, are inadequate to the stormy present. The occasion is piled high with difficulty, and we must rise with the occasion [14-17]. As our case is new, so we must think anew, and act anew. We must disenthrall ourselves, and then we shall save our country' Figure 1. The history of the United States and the cultural model that has asserted itself has been primed by the unjustified idea of infinite technical progress. It has adopted 
technical knowledge as being the basis for unquestionable moral guidance. Whereas an awareness of the limits of that model could well bring down the castle of dreams of unlimited success on which it is based [18].

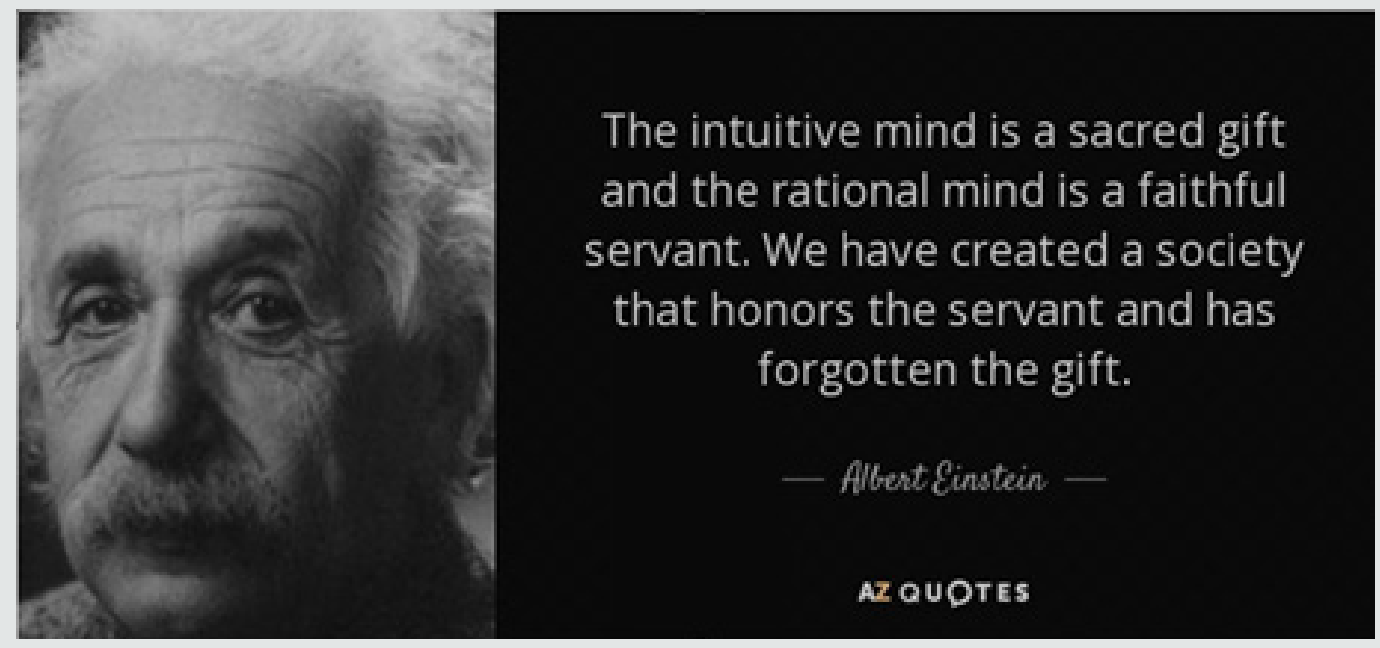

Figure 1: The intuitive mind is a sacred gift and the rational min.

Dramatically, the USA has illuded itself that the time of omnipotence never ends, a mistake the ancient Romans also made, and that the sun could be halted at the zenith indefinitely without even pronouncing Joshua's password. However, as the tenth chapter of the book of Joshua says: 'And there was no day like that before it or after it, that the Lord harkened unto the voice of a man [...]'. So requests like the one above stand even less chance of being heard. Unrestrained liberalism without moral rules has ended up by eroding US society, instead it must be relaunched by such rules to achieve a social cohesion capable of reconstructing a foundation of shared values. This is the first problem, because if the US fails to question its social and economic model it will never manage to understand the new role that the march of history is asking it to play. Or it manages to question its unequal society or it becomes extremely difficult to understand what role a great power like the USA can possibly have in a globalized world. Also Ortega Gasset highlights how coming face to face with suffering and a new awareness this provokes is decisive in order to rethink the sense of human society and solidarity. The United States cannot set itself up as the champion of world social values before experiencing suffering as a result of becoming aware of its own unequal, sick society that, if left to its own devices, could well end up losing itself. The Obama presidency has tried to propose a new model, the right one [19]. But this change questions those wellestablished powers that control the media and that, opposed to this action, weaken it and make it more difficult. In a country where $19 \%$ of the population find it difficult to read and understand a newspaper article, media communication becomes a difficult tool to fight against. The dominant approach seen in past years is deeply engrained in a highly oligarchic society that wants to maintain its position in spite of a society that is weakening at the base. It has pursued this course by always displaying a military force for which the USA spends $50 \%$ of global military expenditure. But even the armed forces are showing signs of weakness given that the number of suicides is sometimes higher than those who die in battle [20].

This choice has led to other countries rearming for instance, Russia and China have started to spend on weaponry again. And while Russia has lost power its nuclear arsenal still remains intact. Other levers used to exercise its dominant power have been to extend US models of the economy and consumption to countries with different histories and recourse to the use of finance governed by lobbies whose interests do not always coincide with those of the USA. Exporting entrenched lifestyle and consumption models to other countries with different histories and traditions presents the risk already indicated by Toynbee in 1948 and as mentioned previously in La Competizione Collaborativa. 'Other countries have absorbed our economic models while maintaining their own cultural models; their history has become part of ours and we must learn to live with it. It is unclear, said Toynbee, how they will react to this Western occupation'. The first reaction he saw was the creation of a Soviet communist empire, however, in Civilization on Trial he stated that it was likely that in the long term India and China would have a much greater impact on life in the West than the hopes of Russia and its Communism. And this is exactly what has happened!

The reactions foreseen by Toynbee were due to the fact that only models of consumption had been exported but not the religious roots, because the economic model could propagate in far less time than a total global culture. And so the Chinese were given a stone instead of bread, whereas the Communist ideal gave them a few grains of nourishment for that spiritual life without which people cannot survive. Today China has to face social problems that its need to grow rapidly had put to one side, in particular the longstanding conflict between its urban areas and agricultural world [21]. The exercise of financial dominance, instead, is especially evident in tensions that have developed between the dollar and the euro. The weakening of the dollar could have oriented "markets" to choose the euro as the reserve currency, perhaps even the settlement 
currency for oil. In order to dissuade this idea the weakening of the euro would seem like a good move.

Weakening the euro meant weakening Germany, but as the German Bund is much stronger than the US Treasury Bond this meant that the euro had to be progressively surrounded and weakened. As in World War II Germany was defeated by conquering Greece, Italy and, lastly, France, with the Normandy landing. In the same way the financial markets first attacked Greece, then Portugal, Ireland and lastly, Spain and Italy. It must be admitted that these countries, which mostly have strong roots in Catholicism, had done everything to get into trouble without any help! Concerning this game plan, we must first get the facts straight. The attack on Italy got under way in early July 2011, playing on the country's fundamentals and the risk of a possible default. But the fundamentals were exactly the same as they had been at the beginning of the year, when the risk represented by the country's growing debt was already quite clear. A trend of rising interest rates could have been unsustainable for Italy's financial equilibrium and economy. Despite the fact that everything was already clear in January the rating agencies didn't see any country risk but then this oversight was rapidly remedied in July when Italy's Treasury Bonds came under fire. In the meantime the bloody campaign in Iraq had come to an end with the announced withdrawal of American troops, also thanks to the capture and killing of Osama Bin Laden two months earlier on 2 May 2011. But the Middle East question continued to be an open issue for the world, together with the unresolved issue and consequences of its threat to Israel [22].

The autumn of "our discontent" grew worse and financial tension hit Italy enabling Wall Street's merchant banks to make profits by speculating on the country's Treasury Bonds. It must be said that in the past ten years Italy had made all the wrong moves, by increasing the debt to capture votes and failing to make the necessary reforms, and so the action was quite justified and, what is more, Italy served it up on a silver plate. However, the anomalies of the rating agencies' assessments continued although to a certain degree they loosened their grip. In January 2012 the agencies lowered their ratings for nine European countries and the European Financial Stability Facility (EFSF) started to become a target for gamblers. But exactly one week later, for the first time, the spread between Italian and German bond rates dropped to 400 base points.

There was an evident contradiction: how come the rating was cut while the spread improved? Technically there was no explanation. But for those interested in coincidences, that same day the Council of Europe stated it would take a harder line as regards the embargo against Iran by ceasing to buy Iranian oil starting from the end of June. As regards Italy, from that moment on the conflicting trend between an improving spread and a rating, public debt, employment and GDP that were getting worse continued to be unexplainable. Are markets rational or not? As always, the most obvious answers are those that are less easy to see [23,5].

And lastly, the current dilemma concerns the role of the BCE as regards the EFSF. Positions of the markets and the Bundesbank have hardened, in particular the latter feels it should not give an open-ended guarantee to purchase bonds on the secondary market. On the other hand, without a protective shield acting as a disincentive against speculation of US banks, which can operate in a market without the rules applying to European banks, and with a Fed monetary policy oriented towards printing an unlimited supply of money, the fund would certainly not last long on the secondary market. The problem for Italy doesn't change because it needs to cure the ills of its public finances or it will always be an easy target for speculation $[11,8]$. But the action of markets and media focus on them make it easy to lose sight of the real problem: is it right to say that markets are rational and never make mistakes as economic theory would have us believe, or is this not true? If, in terms of finance, we are not just rational but also act based on our emotions, and if as a consequence markets are not rational (or not entirely so), the conclusion we can come to is that their trend is perhaps more comprehensible if we understand the true, undeclared interests that move those operators who are mainly capable of influencing the underlying market trends. The choice between a dominant or cooperative position is in effect the key issue for the future of the USA. And the outcome will largely depend on the ability of those governing the country to manage to bring order to and create an equilibrium within the country and the world a finance, which currently seems completely free to act independently. Today such an oversized financial compared to real economy represents a mortal threat to a return to a focus on people and the real economy. This is the challenge not only facing the USA but also the entire world. So it would seem that the very history of the USA, as it has developed over a period of time that enables us to grasp the sense of what has inspired it, is the most obvious demonstration of the theory on which this and my previous book are based. The economy and finance are not the foundation on which to build a good society, that is, a cohesive society inspired to realize values that put people at the centre of our interests $[14,10]$. Exactly the opposite is true: a good society is the foundation on which to create the conditions for a durable, long-term economic and financial equilibrium.

\section{Conclusion}

When I came to the end of my previous work it was still not yet clear how an interpretation of the facts could be confirmed by history. Although I have now made considerable headway the same words I wrote then still hold good today. 'In a context of uncertainty unparalleled in history, one that in no way compares to developments in our ability to dominate nature, people now aspire to a valid order that can remain under their power. An order that is both useful and promotes human progress, capable of reconciling humanity with the extent of its scientific knowledge, which today is perceived as an absolute value, placing it at the service of the search for a more widespread common good'. (La Competizione Collaborativa) Now, perhaps, the boundary of the enigma and this hope seem better defined and can therefore lead to a clearer answer for everyone, while remaining fully aware, however, that responsibilities are always an individual concern. Let us hope that in the middle of all this confusion and uncertainty we manage to 
see the light and find the right path to follow. A path that humanity must find in order to fulfil its destiny and its unique and creative mission on this Earth.

\section{References}

1. Cicero (1999) On the Commonwealth and on the laws. Cambridge University Press, USA.

2. Aristotele (2000) Etica Nicomachea [Nicomachean Ethics]. Bompiani: Milan, Italy.

3. Chomsky N (2006) Failed States: the Abuse of Power and the Assault on Democracy. Il Saggiatore: Milano, Italy.

4. Guardini R (1954) The End of the Modern World. Morcelliana: Brescia, Italy.

5. Keynes JM (1923) The End of Laissez Faire. Essays in Persuasion pp: 272-294.

6. Pezzani F (2011) Cooperative Competition. Egea UBE: Milan, Italy.

7. Pezzani F (2016) The Nobel Prize for Mythical Finance and ?Columbus? Egg?: A Suspension of the Nobel Prize in Economic Sciences? Business and Economic Journal 7: 267.

8. Pezzani F (2016) Independence Day and forgotten equality. Business and Economic Journal 7: 212.

9. Pezzani F (2017) The gold exchange standard and the magic trap of paper money. Journal of Accounting, Finance and Auditing 5: 23-32.
10. Pezzani F (2017) Once upon a time in America and the end of the American dream. Journal of Socialomics, Italy.

11. Pezzani F (2017) Society the foundation of the economy. We need a socio cultural revolution. Scholar's Press: Germany, Europe.

12. Posner R (2010) The crisis of capitalist democracy. Egea UBE: Milan, Italy.

13. Prigogine I (1996) La fin des certitudes. Temps, chaos et les lois de la nature. Odile Jacob: Paris, France.

14. Putnam R (2004) Social capital and individualism. Il Mulino: Bologna, Italy.

15. Russell B (2009) The scientific outlook. Laterza: Rome Bari, Italy.

16. Sigmund F (1971) The Discomforts of Civilization. Bollati Boringhieri: Turin, Italy.

17. Sigmund F (1971) The Future of Illusion. Boringhieri: Turin, Italy. 18. Sorokin P (1941) Social and cultural dynamics. Utet: Turin, Italy. 19. Sorokin P (1941) The Crisis of our age. EP Button \& Co: New York. 20. Toynbee AJ (1949) Civilization on trial. Bompiani: Milan, Italy. 21. Toynbee AJ (1977) Mankind and mother earth. Garzanti: Milan, Italy.

22. Vico G (1725) La scienza nuova [The New Science]. Napoli.

23. Zygmunt B (2005) Liquid Life. Laterza: Bari, Italy.

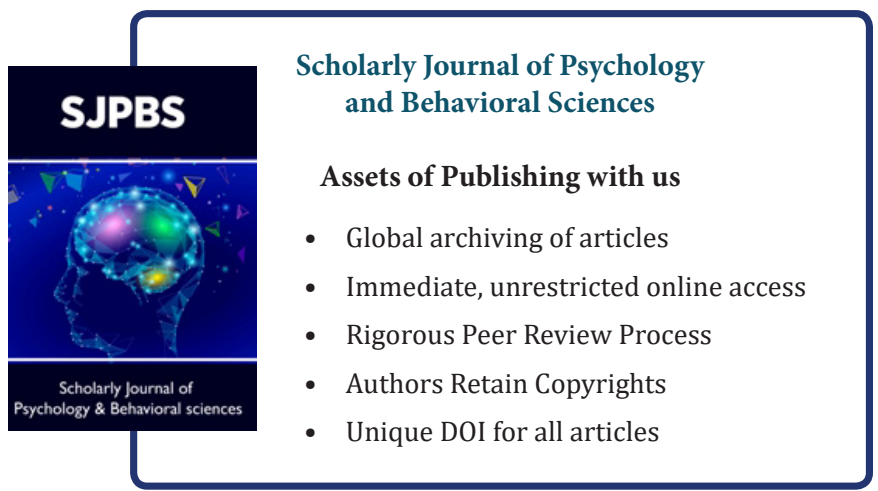

